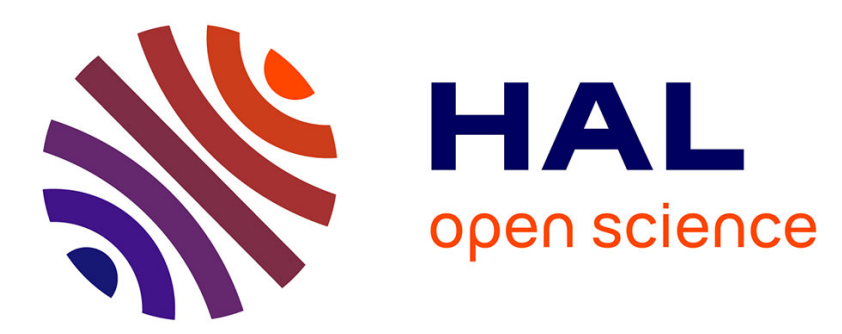

\title{
No evidence of pre-copulatory mate choice by gynes in the facultatively parthenogenetic ant Cataglyphis cursor
}

Florence Helft, C. Doums, T. Monnin

\section{To cite this version:}

Florence Helft, C. Doums, T. Monnin. No evidence of pre-copulatory mate choice by gynes in the facultatively parthenogenetic ant Cataglyphis cursor. Insectes Sociaux, 2016, 63, pp.199-201. 10.1007/s00040-015-0444-0 . hal-01233413

\section{HAL Id: hal-01233413 https://hal.sorbonne-universite.fr/hal-01233413}

Submitted on 25 Nov 2015

HAL is a multi-disciplinary open access archive for the deposit and dissemination of scientific research documents, whether they are published or not. The documents may come from teaching and research institutions in France or abroad, or from public or private research centers.
L'archive ouverte pluridisciplinaire HAL, est destinée au dépôt et à la diffusion de documents scientifiques de niveau recherche, publiés ou non, émanant des établissements d'enseignement et de recherche français ou étrangers, des laboratoires publics ou privés. 
1 No evidence of pre-copulatory mate choice by gynes in the facultatively parthenogenetic ant Cataglyphis cursor

3

$4 \quad$ Florence Helft ${ }^{1,2}$, Claudie Doums $^{2}$, Thibaud Monnin ${ }^{1}$

5

61 Sorbonne Universités, UPMC Univ Paris 06, UMR 7618 Institute of Ecology and

7 Environmental Sciences of Paris, 75005, Paris, France

$8{ }^{2}$ Institut de Systématique, Évolution, Biodiversité, ISYEB, UMR 7205, CNRS, UPMC, École

9 Pratique des Hautes Études, MNHN Département Systématique et Évolution, 45 rue Buffon,

10 CP 39, 75005 Paris, France

Corresponding author: Florence Helft

13 Address: Sorbonne Universités, UPMC Univ Paris 06, UMR 7618 Institute of Ecology and

14 Environmental Sciences of Paris, 75005, Paris, France

15 E-mail: Florence.helft@gmail.com

16 Tel: +33144275861

\section{ABSTRACT}

19 Virgin queens (gynes) of the ant Cataglyphis cursor mate on the ground at the nest entrance, 20 where they benefit from the protection of nestmate workers. By carrying out mating tests in

21 the laboratory, we show that gynes mate with the first males they encounter, suggesting the 22 absence of pre-copulatory mate choice by gynes. This is in agreement with the recent finding 23 that workers behave aggressively towards foreign males and could thereby exercise a form 24 of inclusive mate choice, which could replace pre-copulatory mate choice by gynes. 


\section{KEYWORDS}

Eusocial insects, Sexual selection, Inclusive mate choice, Multiple mating.

(7)

8

Sexual selection favours phenotypic traits affecting reproductive success, for instance through better access to a sexual partner resulting from increased competitiveness among individuals of the same sex (intra-sexual selection) or from increased attractiveness towards individuals of the opposite sex (inter-sexual selection). While sexual selection has received considerable attention in solitary organisms it has been the subject of less attention in social species, especially in social insects (Davidson 1982; Boomsma et al. 2005; Boomsma 2007; den Boer et al. 2010; Boomsma 2013). This might be linked to the fact that in the latter sexual partners are committed for life, which minimizes the potential for sexual selection (Boomsma 2013). Furthermore, the widespread occurrence of nuptial flights associated with a high mortality of sexuals favours the evolution of traits that optimize and access to partners (e.g. flight abilities, partner detection) but not those linked with pre-copulatory sexual selection (e.g. weaponry, ornaments, courtship behaviours) (Boomsma et al. 2005; Baer 2011).

However, some eusocial insects mate multiply on the ground near the nest entrance. This lowers the mortality of gynes (young virgin queens) since they are in the presence of protective workers and can retreat into the nest. Moreover, workers may directly participate in gyne mate choice, i.e. exercise a form of inclusive mate choice (Cronin et al. 2011). Indeed, gynes and workers have the same interests in choosing the "best" males. This is because workers typically do not reproduce and obtain indirect fitness by helping related queens. Workers would therefore benefit from helping related gynes to choose good mates, 
and could achieve this by physically preventing males of poor quality from accessing gynes.

Gynes would benefit from deferring mate choice to workers if doing so minimises their exposure to desiccation and predation. In addition, workers may collectively be in a better position to make an optimal choice than hard-pressed gynes.

The involvement of workers in mate choice has been suggested in army ants (Franks \& Hölldobler 1987), Argentine ants (in the invasive range, Sunamura et al. 2011) and the facultatively parthenogenetic ant Cataglyphis cursor (Cronin et al. 2011; Helft et al. 2015). In the latter two species, workers are aggressive towards all foreign males who enter or come near the nest searching for a receptive gyne. Worker aggression may be a form of inclusive sexual selection by workers if they differentially affect some male phenotypes. This is indeed what occurs in C. cursor. Gynes are produced by the multiply mated queen (Lenoir et al. 1988; Pearcy et al. 2004) and workers are highly related to both parthenogenetically produced gynes (clones of their mother, $r \sim 0.5)$ and sexually produced gynes $(r=0.44$ on average) (Doums et al. 2013), and a recent study showed that worker aggression toward males affected male relative mating potential, increasing it for lighter males and decreasing it for heavier males (Helft et al. 2015). The present study therefore aims at determining whether $C$. cursor gynes exercise pre-copulatory mate choice or not. We observed mating behaviour of gynes in the presence of two males under laboratory conditions. The males differed in the level of harassment they had experienced from workers, with one of the two males previously exposed to worker aggression for 10 minutes while the other was not exposed to workers.

We used 115 sexuals (46 males and 69 females) from 22 colonies which had been produced in nature but which emerged in the laboratory, allowing us to be certain of their virginity (see Supplementary material). We carried out 23 mating tests, each using one focal 
gyne and two males. In addition, two other gynes were used during the exposure phase of males to worker aggression immediately prior to the mating test (below). The focal gyne was placed alone in a mating arena to which it could habituate. Simultaneously, one male was placed in another box containing a second gyne in a mesh cage, so that he could perceive her presence but could not mate (treatment without workers or W-). A second male was placed in a third box containing the third gyne, also encaged, but with the addition of 50 of the gyne's nestmate workers that could aggress the male as shown in Helft et al. (2015) (male $\mathrm{W}+$ ). After 10 minutes, the two males were moved to the mating arena containing the focal gyne and matings were observed for 10 minutes. All individuals were used only once. The three gynes used in each test were sisters and at least 19 days old, since previous observations suggest that most gynes are sexually active at this age. The two males were brothers and unrelated to the gynes. We selected males of the same age and size (see Supplementary material), hence they differed only in their previous exposure to worker harassment.

Mating attempts were unambiguous. The male mounted above the gyne with his front and middle legs embracing her thorax and only his hind legs remaining on the ground, made frenzied antennae contacts and attempted to copulate by rubbing the tip of his abdomen around that of the gyne. A successful attempt ended by the intromission of the male's genitalia into the female gaster for several seconds and was thus recorded as a mating even though we do not know whether sperm transfer occurred. Using BioLogic software (Dimitri Missoh, http://swarmy.free.fr/wordpress/2009) we recorded the latency before the first mating attempt, the number of mating attempts, and the number and duration of mating (i.e. duration of copulation). All statistical analyses were conducted using R-Gui software (version 3.0.2, 2008). 
because she was not receptive or stressed by the experimental setup, e.g. by the absence of nestmate workers or colony odour. Twenty matings occurred in the remaining 14 tests. They lasted $1 \mathrm{~min} 10 \mathrm{~s} \pm 30 \mathrm{~s}$ (mean $\pm \mathrm{SD}$ ). C. cursor queens mate multiply (Lenoir et al. 1988,

Pearcy et al. 2004) and multiple mating by gynes was indeed observed during our 10 minutes tests. Nine gynes mated once, four mated twice (two with the same male and two with both males) and one mated thrice (with both males). Similarly, males can mate multiply in this species (Cronin et al. 2011) and multiple mating by males was also recorded, with 14 males mating once and three mating twice (Fig. 1).

Although all $\mathrm{W}+$ males were aggressed by workers during the exposure phase that 107 immediately preceded the mating test (from 22 to 201 aggressions in 10 minutes, median = 108 94), this had no effect on the outcome of mating tests. W+ and W- males did not differ in 109 latency before the first mating attempt (Wilcoxon test: $p=0.9$ ), number of mating attempts 110 (Wilcoxon test: $p=0.7$ ), number of matings (Fisher exact test: $p=0.54$ ) or duration of 111 matings (Wilcoxon test: $p=0.7$ ) (Fig. 1). Both males attempted mating in 11 out of the 14 tests where mating occurred. The 113 gyne always mated with the first male who attempted mating, usually on his second or third 114 attempt, and she always mated before the second male attempted to mate (Fig. 1). This 115 suggests that gynes mated indiscriminately, at least for their first mating, and supports the 116 hypothesis that gynes largely defer pre-copulatory mate choice to workers (Helft et al. 117 2015). Note, however, that this does not preclude post-copulatory sperm selection (Baer 118 2011). For instance, cryptic mate choice by gynes could occur by rejecting the sperm of less 119 fit partners and/or by controlling the duration of mating (Oppelt and Heinze 2007). In 120 several instances we observed that gynes in copula turned around and bit the mounting 
121 male and that this ended the copulation. This suggests that gynes have at least some degree

122 of control over mating duration, and it is interesting in this context to note that mating

123 duration was indeed very variable, lasting from $10 \mathrm{~s}$ to $1 \mathrm{~min} 57 \mathrm{~s}$ (Fig. 1).

124 The indiscriminate mating by gynes observed in our experiment is in apparent 125 contradiction with previous field observations that gynes can refuse to mate and indeed 126 actively avoid most mating attempts (Lenoir et al. 1988, Cronin et al. 2011). However, in 127 these field observations gynes were likely already mated since most had lost their wings and 128 wing loss is a good predictor of being mated (Doums et al. 2013), hence they were likely not 129 seeking to mate but were seeking to be transported by workers to a new colony (Lenoir et al. 1988, Chéron et al. 2011). Further studies should investigate whether all matings result in

131 the transfer of sperm and/or seminal secretions, whether mating duration affects this 132 transfer, and whether gynes can adjust mating duration according to male quality or mating 133 status.

\section{ACKNOWLEDGEMENTS}

136 We thank C. Haussy for helping with colony collection, R. Péronnet for helping in rearing the ants, and A. L. Cronin for linguistic help.

REFERENCES

140 Baer B (2011) The copulation biology of ants (Hymenoptera: Formicidae). Myrmecol News $14: 55-68$

142 Boomsma JJ (2007) kin selection versus sexual selection: why the ends do not meet. Curr Biol 17:673-683 
144 Boomsma JJ (2013) Beyond promiscuity: mate-choice commitments in social breeding. Philos Trans R Soc B 368:2-21

146 Boomsma JJ, Baer B, Heinze J (2005) The evolution of male traits in social insects. Annu Rev Entomol 50:395-420

Chéron B, Cronin AL, Doums C, Fédérici P, Haussy C, Tirard C, Monnin T (2011) Unequal resource allocation among colonies produced by fission in the ant Cataglyphis cursor. Ecology. 92: 1448-1458

Cronin A, Monnin T, Haussy C, Doums C (2011) Opportunities for mate choice in the fissionperforming ant Cataglyphis cursor. Ecol Entomol 36:522-525

Davidson DW (1982) Sexual selection in harvester ants (Hymenoptera: Formicidae: Pogonomyrmex). Behav Ecol Sociobiol 10:245-250

den Boer SPA, Baer B, Boomsma JJ (2010) Seminal fluid mediates ejaculate competition in 156 social insects. Science 327:1506-1509

Doums C, Cronin AL, Ruel C, Fédérici P, Haussy C, Tirard C, Monnin T (2013) Facultative use

Franks NR, Hölldobler B (1987) Sexual competition during colony reproduction in army ants. Bio J Linn Soc 30:229-243

162 Helft F, Monnin T, Doums C (2015) First evidence of inclusive sexual selection in the ant Cataglyphis cursor: worker aggressions differentially affect male access to virgin queens. Ethology 121:1-10 Cataglyphis cursor (Hymenoptera, Formicidae). Psyche 95:21-44 
167 Oppelt A, Heinze J (2007) Dynamics of sperm transfer in the ant Leptothorax gredleri. Naturwissenschaften 94:781-786

169 Pearcy M, Aron S, Doums C, Keller L (2004) Conditional use of sex and parthenogenesis for workers and queen production in ants. Science 306:25-28

171 Sunamura E, Hoshizaki S, Sakamoto H, Fujii T, Nishisue K, Suzuki S, Terayama Y, Tatsuki S (2011) Workers select mates for queens: a possible mechanism of gene flow restriction between supercolonies of the invasive Argentine ant. Naturwissenschaften 98:361-368

175 
176 Figure 1: Timing of mating attempts and duration of matings. The $x$-axis shows the duration

177 of the mating tests in min. On the y-axis, labels indicate colony identity, as well as gyne

178 identity for colonies which provided multiple gynes. The shorter bars indicate mating

179 attempts. A few that were largely overlapping have been slightly moved sideways for clarity.

180 The taller bars indicate actual mating (copulation), with their width indicating the duration

181 (given in s). $\mathrm{W}$ - males are in white and $\mathrm{W}+$ males are in black.

182

183

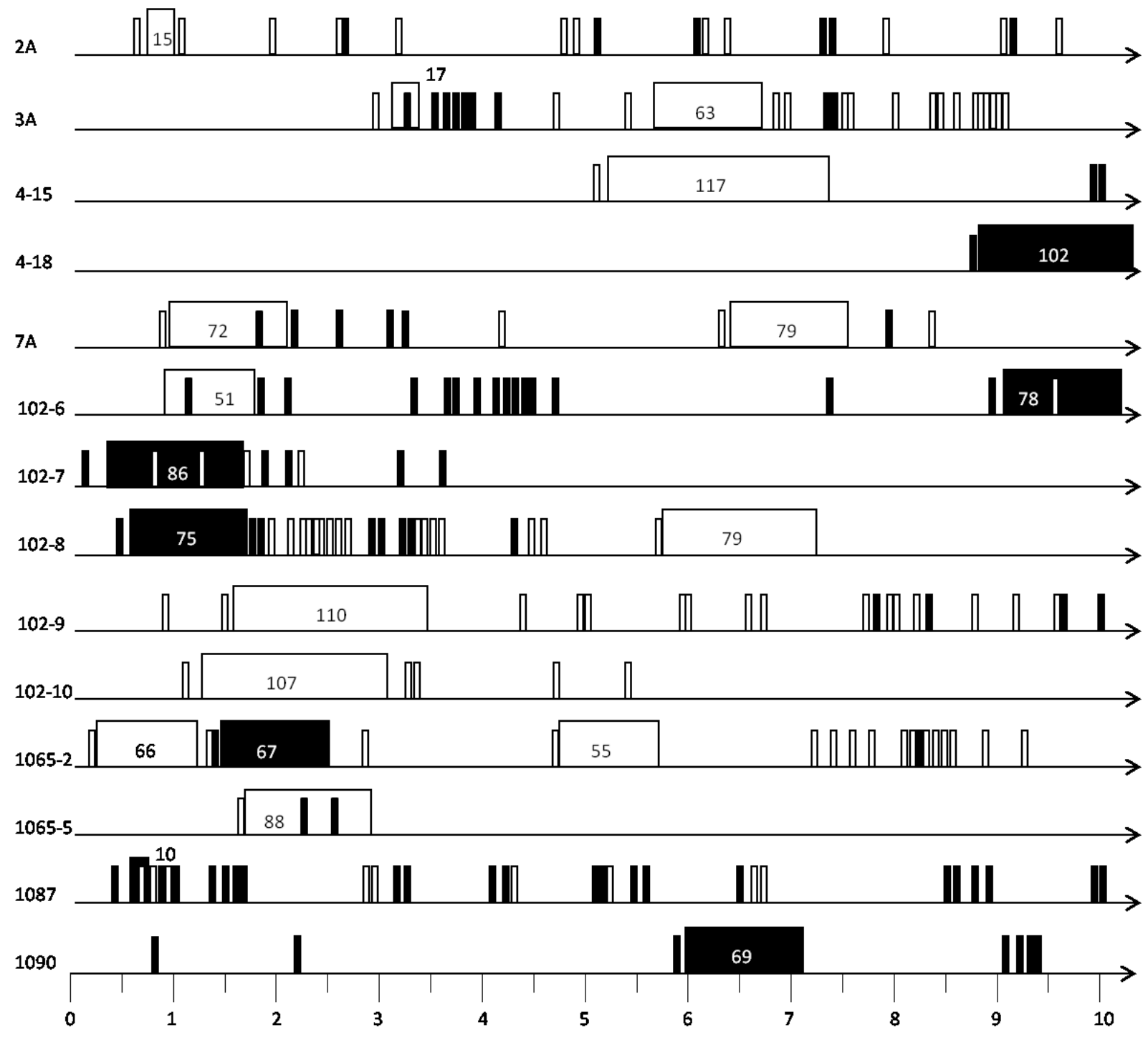

